\begin{tabular}{|c|c|}
\hline 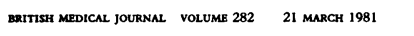 & 857 \\
\hline \multicolumn{2}{|l|}{ Beyond the Surgery } \\
\hline \multicolumn{2}{|c|}{$\begin{array}{l}\text { General practitioner to the actors } \\
\text { MICHAEL COIGLEY }\end{array}$} \\
\hline 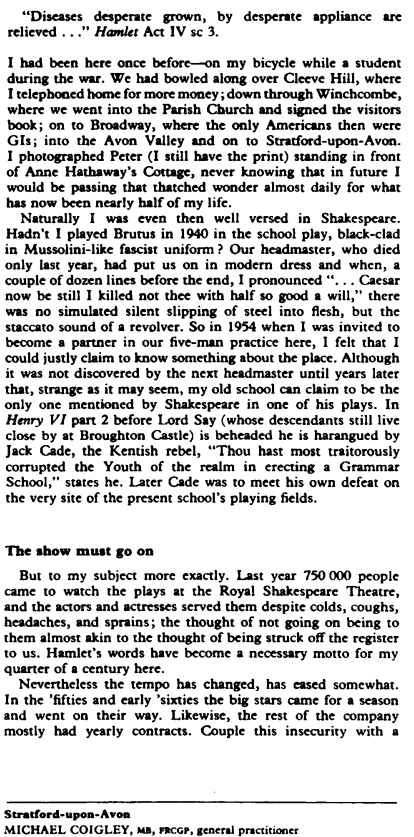 & 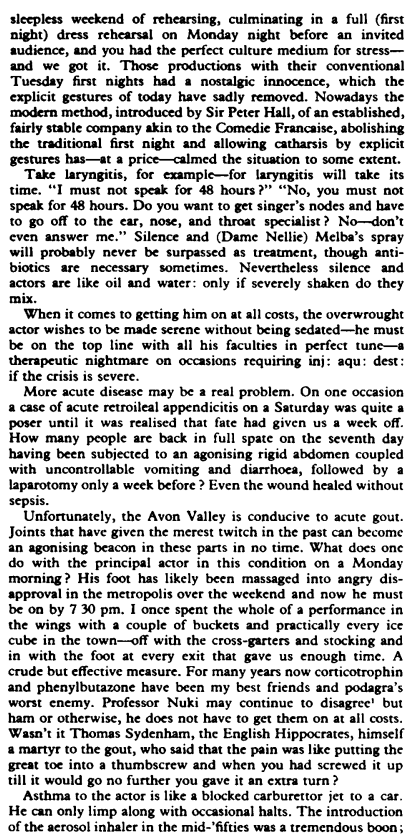 \\
\hline COIGLEY, Ma & 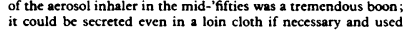 \\
\hline
\end{tabular}

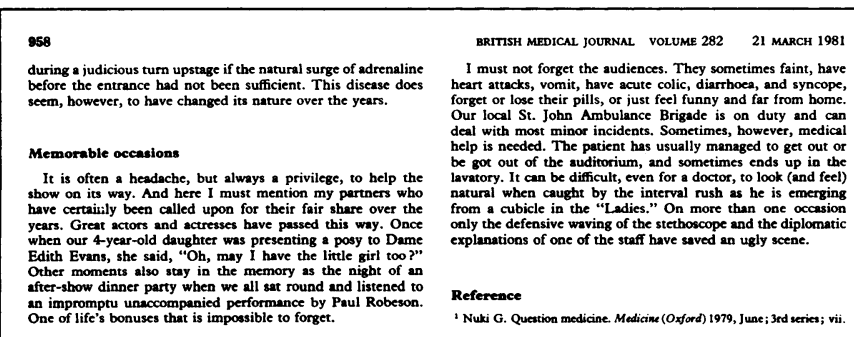

\section{Pitfalls in Practice}

\section{Employment law}

III: The contract

NORMAN ELLIS

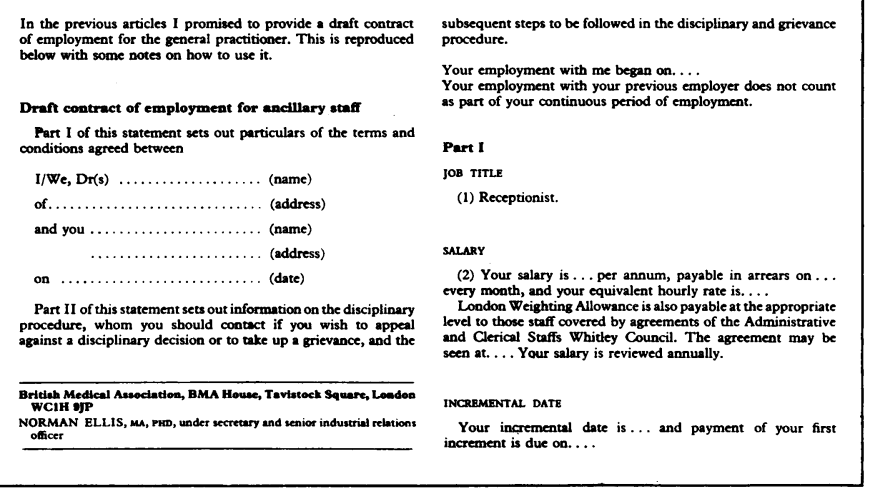

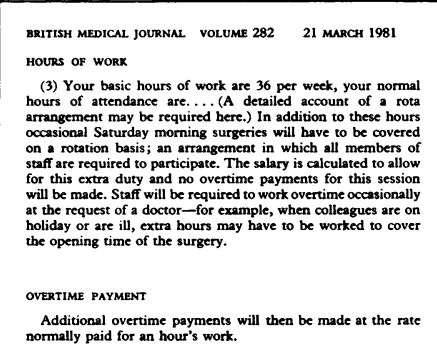

Additional overtime payments will
normally paid for an hour's work.

ANNUAL LEANE

(4) You are entited to four weets' paid annual leave, which is
normallt tatken between Easter and Christmas of each year.
Reasong ble nocice must be siven of your Reasonable notice must be given of your intention to atke leave,
and all leave mustr be arranged with the doctor in charge so that
there is adequate cover for the surgery there is adequate cover or the surgery.
Leve must te traken by the end of the calendar year and may
not be accumulated from one year to the next unless by prior

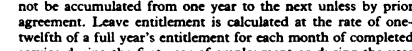
service during the first year of employment of during the year
of resignation-tor example, 3 February to 1 March would
equal one month. If a member of staff has anticipated his or $h e r$ equal one month. If a member of staff has anticipated his or her
leave entitement before termination an appropriate deduction

BaNK HoLDAYS

The surgery will be closed on official bank and public holidays
and any proclaimed National holidays. SICK LEAVE

(5) The sick pay scheme may be revised or withdrawn at the
discretion of the employer. discretion of the employer.
The entitlement in any 12 month period is as follows:

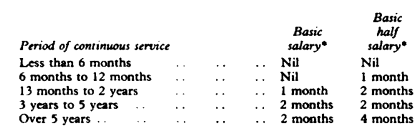

The following deductions will be made from an allowance equal to full basic salary, irrespective of whether you register a
claim. So you are advised to ensure that you claim all your
entilements under these Acts. (Marriced women exercising their entitlements under these Acts. (Married women exercising their
right to be exempted from the payment of National Insurance
contributions shall be deemed, in regard to the scheme for contributions shall be deemed, in regard to the scheme for
sickness payments, to be insured in their own right.)
(o) The amounts of sickness (a) The amounts of sickness or invalidity benefits recoverable
under National Insurance Acts, if appropriatc.
(b) The amount of injury benefit receivable under the National (b) The amount of injury benefefit receivable under the National
(Industrial Injuries) Act, if appropriate.
(c) The amount of earningssrelated supplement to sickness

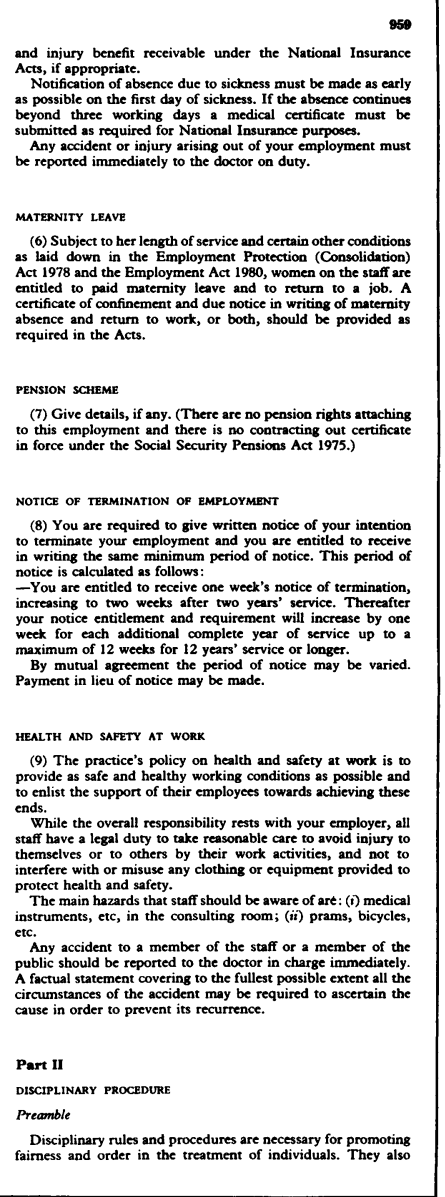

960

assist a practice to operate effectively. Rules set standards of conduct and performance at workt; procedure helps to ensure
that the stsandarts are adhered to ond also provides a fair method of dealing with alleged failures to observe them.
Disciplinary procedures should not be viewed primarily as a
means of imposing sanctions. They should also be designed to

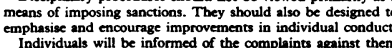

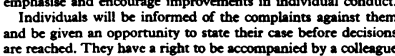
are reached. They have a right to be accompanied by a colleague
ac all stages in the procedure. Any warning given in this pro-
cedure will be deemed to have Lapsed after one year, subject to satisfactory conduct.
The following disciplinary procedure will apply:
Cousselling - If there is thought to be cause for action under chis disciplinary procecdure, you will first be asked to attend
discuss the matrer with the doccor in charge. The proceeding

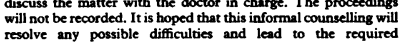
improvement.
Verbal warming-If following this there is continued cause for
concern, there will be a furber meeting with the doctor in concern, there will be a further meeting with the doctor

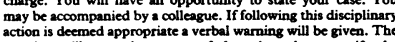

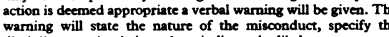
disciplinary action being taken, indicate the likely consequencer
of commititing missonduct again, und state, if appropriate, the

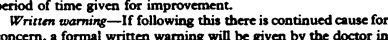
concern, a formal writiten waming will be given by the doctor in
charge stating the nature of the complaint and that if no improve charge stating the nature of the compleint and that if no improve
ment is forthoming it may restlt in your dississal.
Dismissal-If there is no improvement you may then be dismissed. Where circumstances permit, the right of appeal
Appeal-What
against dismissal should be to a doctor who has not been directly Serious misconduct-There are varying degrees of seriousness
of misconduct, so this procedure may be started at any stage depending on the severity of the misconduct. A few examples
of gross misconduct that would justify summary dismissal of gross misconduct that would justify summary dismess
without prior warning are theft, abusce of medicines, and serio
breach of confidentiality. In some circumstances where serious breach of confidentiality. In some circumstances where serious
misconduct is thought 0 have occurred, the member of staff
concerned may be suspended on full basic selary pending an GRIEVANCE PROCEDURE

If you have any grievance relating to your employment you
should raise this with Dr.... Minor grievances may be raised orally, but serious grievances must be in writing. This .... day of ........... 19

1 acknowledge receipt of this contract of employment and
agree to be bound by it. I understand that you retained a copy
of this signed contract. Signed

This
BRITISH MBDICAL JOURNAL VOLUME $282 \quad 21$ MARCH 1981 Notes of guldence on the Draft Contract of employment (1) Date of contract-Fill in date when Contract is signed.
The date employment begins, for example, is important because

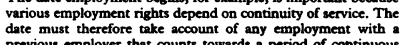
employment by the that counts towards a period of continuous

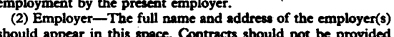

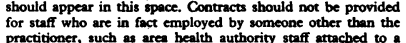
prectice.
(3) Title of iob-It is important that this should adequately
describe the scope of the employee's job as the employee describe the scope of the employee's job as the employee

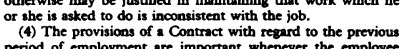

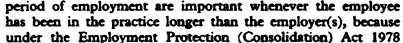
under the Employment Protection (Consolidation) Act 1978
when a prectice is transferred from one doctor to another, the When a practice is transferred from one doctor to another, the
period of ef employment of an employece in the praccice at the time
of the transfer would normally count as a period of employment with the transferee and the transfer shall not break the con-
tinuity of the period of employment.
Thus, whereas a prectitioner who takes on a new employee Thuss, whereas a practitioner who thakes on an new employee
will incur very few obligitions during the first 52 wects, it it
only at the end of this period that, for example, she bocomes entited to compensation if she is unfairly dismissed unless the

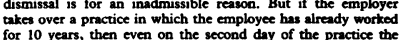

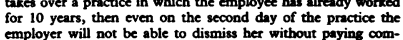
employer will not be able to dismiss her without paying com-
pensation based on the full 10 year' employment
(5) Holidays - The parties are free to matke beir own arrangements in this regard. In small practices one of the most frequent
sources of diffeculty concerns staff who ere unable to suranger their bolidays so that they yd onot coincide. The form suserses
one way in which this difficulty may be met, an alternative

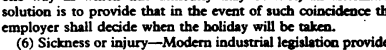

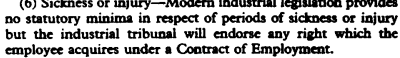
(7) Pensions-Some practices run their own pension schemes:
if they do and if a contracting out certificate is in force then the

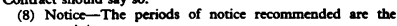
staturtory minima.
(9) Discipline-The Act provides that the Contract of (9) Discipline-The Act provides than the Contract of
Employment should telll an cmployec where details of the
disciolinert disciplinary action are to be found.
(10) Grievance procedure- The Act provides that the
Contract of Employment must describe the grievance procedure. JOB Description

This should normally be a separate and distinct document
front the contract istelf. It should set out the main task of the

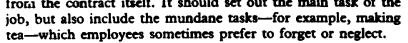
This is the fifth of six articles on employing staff. 